\title{
Lessons from the autumn 2014 flash floods in the city of Nîmes and its neighborhood (France): behavior of several mitigation dams and hydrological analysis
}

\author{
Catherine Fouchier ${ }^{1, a}$, Patrice Mériaux ${ }^{1}$, Guillaume $\mathrm{Pla}^{2}$, Jean-Luc Nuel ${ }^{2}$, Etienne Retailleau ${ }^{3}$, Paul Royet $^{1}$ \\ ${ }^{1}$ IRSTEA, "Recover" Research Unit,CS 40061, 13182 Aix-en-Provence Cedex 5, France \\ ${ }^{2}$ City of Nimes, 152 avenue Robert Bompard, 30000 Nîmes, France \\ ${ }^{3}$ Gardon rivers SMAGE, 6 avenue du Général Leclerc, 30000 Nîmes, France
}

\begin{abstract}
The Languedoc area, in Southern France, is prone to autumnal flash floods which are characteristic of the Mediterranean climate. To cope with this threat, the local authorities have chosen to build several dams on the main dangerous rivers of the area. We have focused on the flood mitigation facilities of two operators: the City of Nîmes and the Gardons Rivers Managing authority. After the catastrophic flash flood of October 1988, the city of Nîmes built flood mitigation dams on many of its high-risk streams. These flood barriers worked several times during the intense rainfalls of autumn 2014. The on-site conclusions drawn from these floods and the computation carried out with hydrological models confirmed how well the dams functioned. In 2010, the Gardons Rivers Managing authority built a flood mitigation dam on the Esquielle River to protect the village of Saint-Geniès-de-Malgoirès. The spillway of this dam worked for the first time in the autumn of 2014. We analyzed one of the major floods monitored on that occasion at its outlet. The goals of this study are: (i) to evaluate dams efficiency and (ii) to test, on a catchment which was not used for its calibration, the AIGA flash flood warning method, which was developed by IRSTEA.
\end{abstract}

\section{Introduction}

The south-eastern side of the Massif Central, in France, and particularly the Cévennes Mountains, periodically experience flash floods, often occurring in the autumn. This mountainous area is indeed hit by the storm cells which appear in late summer over the Mediterranean, and which are carried by southern air flows.

At the beginning of autumn 1958, a series of intense precipitation events affected the Gard administrative area (Département $d u$ Gard) whose rivers are mainly located in the Cévennes Mountains or at their foothills. Catastrophic floods occurred on September 30 and October 4, destroying 9 major bridges and killing 36 people, 18 of whom died on the road between the cities of Nîmes and Alès. In the wake of these events, the Administrative authority of Département $d u$ Gard launched a program aimed at building five big flood mitigation dams. Built in the 1960s and $70 \mathrm{~s}$ and controlling watersheds whose areas range between 45 and $110 \mathrm{~km}^{2}$, they can hold a combined capacity of 55 million $\mathrm{m}^{3}$.

Since the 1980s, building great dams has considerably slowed down in France. But Nîmes' very localized October 1988 event and the devastating floods of September 8th and 9th 2002 which hit a major part of the Département $d u$ Gard have boosted a new interest in flood mitigation dams smaller than the ones built in the 1960s ans 1970s, which have shown limitations in terms of social acceptability and impacts.

This article presents two dams building programs which were implemented in the late 1990s in the city of Nîmes and its surrounding area. The operation of these dams is analyzed in the light of the intense rain and storm events which occurred in autumn 2014 in the Département $d u$ Gard. The data provided also provide the opportunity to test a flash flood warning method developed by Irstea $[1,2]$, on a catchment which was not used for its calibration.

\section{Flood-mitigation structures in the City of Nîmes}

\subsection{Presentation of the Flood-mitigation CADEREAU program and of the implemented facilities}

\subsubsection{Context and Flood Prevention Strategy}

The city of Nîmes is located at the confluence of six intermittent Mediterranean water courses that are locally called Cadereaux. These Cadereaux run in a north west south east direction and flow into the coastal Vistre river

\footnotetext{
a Corresponding author: catherine.fouchier@irstea.fr
} 
(see Fig. 1). Their catchment areas range from 5 to 30 $\mathrm{km}^{2}$. They drain a total area of about $100 \mathrm{~km}^{2}$ which can be divided in three main parts: the upstream karstic hills, the median urban area and the downstream Vistre river plain. This geographical location explains why the city of Nîmes has been regularly affected by floods, some of them catastrophic, throughout its history.

The discharges of these Cadereaux are strongly influenced by meso-scale Mediterranean convective meteorological systems and by the geological characteristics of the catchments which belong to the Fontaine de Nîmes karstic system.

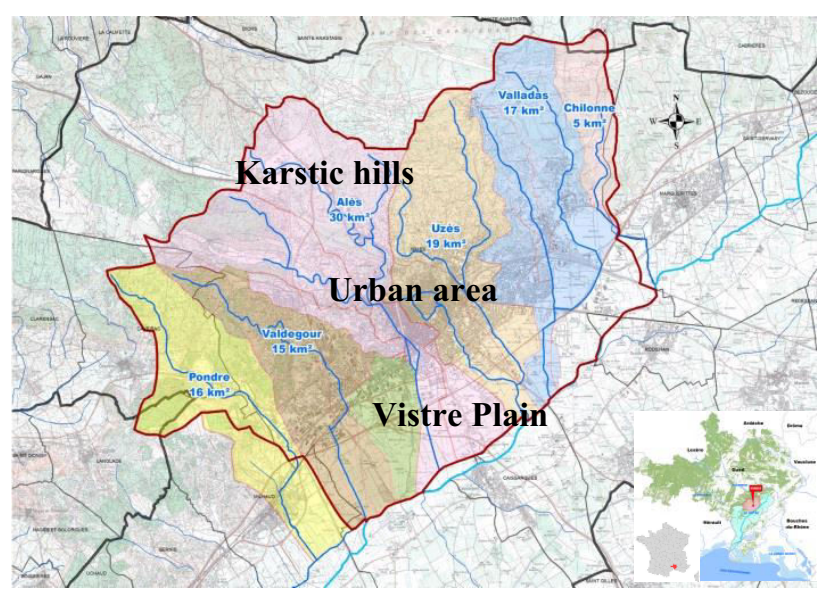

Figure 1. Map of the watersheds of the 6 Cadereaux in the city of Nîmes.

The $20^{\text {th }}$ century urban extension has highly increased the number of human and socio-economic stakes exposed to the flood risk in this area. Currently, there are over 60,000 people and 6,000 businesses in the flooding area of the Cadereaux.

This extremely high vulnerability to torrential runoffs was tragically highlighted by the event of October 3 , 1988 (see Fig. 2). At that time, rainfall exceeded $420 \mathrm{~mm}$ in 7 to 8 hours, generating specific flow rates that ranged from 20 to $25 \mathrm{~m}^{3} / \mathrm{s} / \mathrm{km}^{2}$. In several places, water levels in the city centre rose above 2 meters. Overflow volumes that transited through the city are estimated at 14 million $\mathrm{m}^{3}$. This event caused the death of 9 people and affected 45,000 other. The total economic cost of the event amounted to $€ 610$ million (in 1989 value). The return period of this event was estimated between 2,000 and 10,000 years, depending on the site

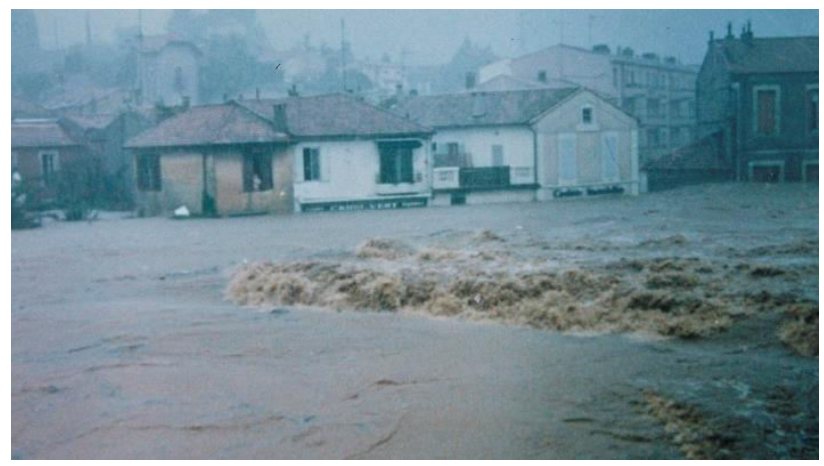

Figure 2. Overflowing of the Alès Cadereau at the entrance of Nîmes' urban area - October 3, 1988.
Subsequently, the city of Nîmes, in partnership with all the stakeholders and experts of flood risk management, implemented a flood prevention strategy, detailed in a general program called the "CADEREAU program". It consists of three successive operational action programs:

- the 1990 - 2006 Plan de Protection Contre les Inondations - PPCI (Flood Protection Plan), representing an investment of $€ 69$ million, co-financed by the French government, the Languedoc-Roussillon administrative area, and the Département du Gard;

- the 2007 - 2014 Programme d'Actions de Prévention des Inondation Nîmes Cadereaux (PAPI I, City o Nîmes Cadereaux Flood Prevention Action Program), representing an investment of $€ 87$ million co-financed by the French government, the Languedoc-Roussillon administrative area, the Département du Gard, and the Nîmes city urban community;

- the 2015 - 2020 Programme d'Actions de Prévention des Inondation Nimes Cadereaux (PAPI II), with a provisional budget evaluated at $€ 102$ million.

Recent floods (September 8-9, 2002, September 6-8, 2005 , and October 10, 2014) highlighted the importance of this strategy and how urgent it is to persevere with these measures. In terms of a structural reduction of the "torrential flood" hazard represented by the Cadereaux, the current strategy, validated in 2007 , consists in evenly protecting the six Cadereaux in preparation for an event similar to September 6-8, 2005, which was evaluated as having a 40 -year return period. To do so, the following modifications have been made to the watercourses:

- building of flood-mitigation structures in the karstic hills on the catchment areas upstream of the urban area;

- resizing of runoffs in the urban area;

- creating hydraulic transparencies and compensation structures downstream of the urban area in the Vistre river plain, so as not to worsen downstream flooding.

The PPCI has enabled to build 18 flood-mitigation dams and 4 downstream compensation structures. The PAPI I completed the upstream flood-mitigation capacities and restructured runoffs from the urban area of the Alès Cadereau (bringing the runoff capacity from 25 to $120 \mathrm{~m}^{3} / \mathrm{s}$ ). The PAPI II should make it possible to complete hydraulic infrastructures on the Alès Cadereau and to restructure runoffs from the Uzès Cadereau (bringing the runoff capacity from 10 to $80 \mathrm{~m}^{3} / \mathrm{s}$ ). Hydraulic infrastructures on these two cadereaux have been prioritized since they represent over two thirds of the damages caused by flooding in the municipality, damages which have been estimated at a yearly average of $€ 50$ million.

\subsubsection{The implemented flood mitigation structures}

Within the framework of the CADEREAU program, the following flood mitigation structures were built, amounting to approximately $€ 22$ million:

- 18 upstream flood-mitigation basins, with a total storing capacity of $790,000 \mathrm{~m} 3$ (this storing capacity is 
completed by a quarry on the Pondre Cadereau which can store some 1.5 million $\mathrm{m} 3$ );

- 4 downstream compensation basins, which can store a total of $600,000 \mathrm{~m} 3$.

The upstream flood-mitigation dams were initially sized to attenuate a flood triggered by a 4-hour design rainfall, with a 40-year return period over one hour. Following the September 6-8 2005 event, this goal was adjusted to allow for flood mitigation of a similar hydrological event (both in peak flows and in volume), whose return period was estimated at 40 years.

Dam levels vary between 2 and $10 \mathrm{~m}$, with a storage capacity ranging from 10,000 to $370,000 \mathrm{~m}^{3}$. Most of these structures are zoned embankments with a clay core used as a main waterproof screen. They comprise nongated bottom outlets, the sizing of which is calculated beforehand to ensure the design flood is mitigated. The upstream part of the bottom outlet is protected against log and rock jam by a fence.

The worksites were supervised by a project manager qualified in large dams and benefited from IRSTEA's technical assistance thus leading to implementing building methods well fitted to the context of the Cadereaux torrential floods such as:

- driving anchoring clay keys deeper depending on the presence of cracked limestone substratum

- specific treatment of crackings in the limestone massif;

- creating a complete internal clay core, when early structures were made with a simple clay anchoring key;

- acceptance of earthworks for the clay anchoring key and a continuous supervision of the implementation of the waterproof clay core layers;

- modifications of the concrete encasement of the bottom outlets, to improve water tightness at the clay-concrete interface;

- modifications to geometries and sizing of the bottom outlet upstream protection screen following the collapse of some fence due to plant debris deposits when water levels fall (see Fig. 3).

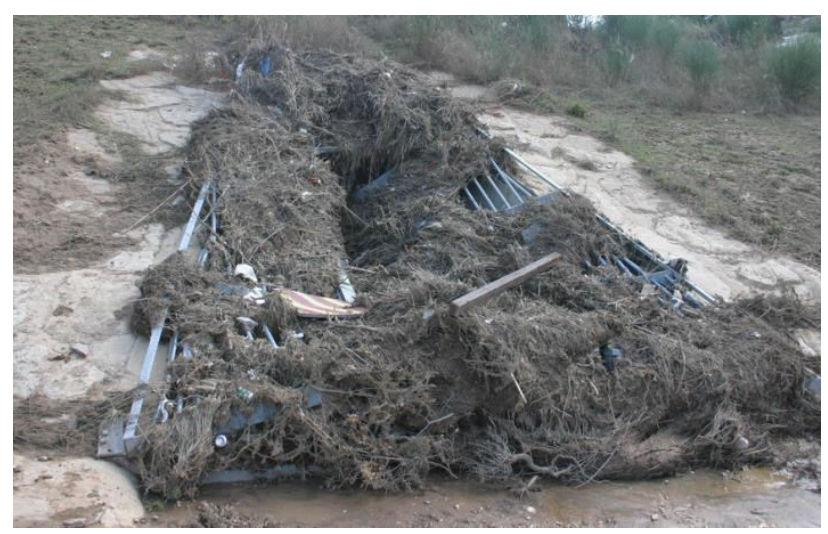

Figure 3. Example of bottom outlet fence collapse.

The safety spillways of structures were designed in order to withstand a flood - called safety flood [3] - that would be twice as powerful as the 1988 flood, without suffering any structural damage.

\subsubsection{Post-flood maintenance and monitoring of the flood mitigation devices}

Under French regulation on large dams, the city of Nîmes is responsible for the regular monitoring of the above hydraulic works and has to keep a record of this monitoring. This regular monitoring includes visual inspection twice a year and vegetation maintenance (weed cutting, shrub elimination). During flood events, a real time monitoring is implemented thank to the use of real-time water level sensors (5-min time steps), video monitoring and on field visual inspection. Each time the water level reaches more than $1 \mathrm{~m}$ above a bottom outlet, a post-flood report is carried out and log jams and rocks are withdrawn within 24 hours after the reservoir is empty.

A general analysis of all the hydraulic structures was carried out by specialized contractors for the more severe events (2002, 2005, 2010 and 2014). Finally, In-Depth Technical Analyses were carried out in 2008, 2010 and 2015. The last exhaustive review of 2015 took place following the event of October 10, 2014. An analysis of this event and the behavior of the hydraulic structures, particularly of the Roquemaillère Basin located on the Alès Cadereau, are presented in further sections of this article.

\subsection{October 10, 2014 Meteorological Event over the Town of Nîmes}

The October 10, 2014 event occurred in an autumn with many such episodes across the French Mediterranean area. The city of Nîmes had already been affected by less severe events on September 18 and 29, 2014. The Cadereaux karstic catchment area was hence already highly saturated when intense precipitation fell on the north-western part of the city on October 10th. Figure 4 shows, at the spatial resolution of $0.25 \mathrm{~km}^{2}$, the accumulated rainfall estimated by meteorological radars between $2 \mathrm{am}$ and $1 \mathrm{pm}$. More than $400 \mathrm{~mm}$ of rainfall were estimated on some $0.25 \mathrm{~km}^{2}$ pixels in the upstream part of the Cadereaux catchments.

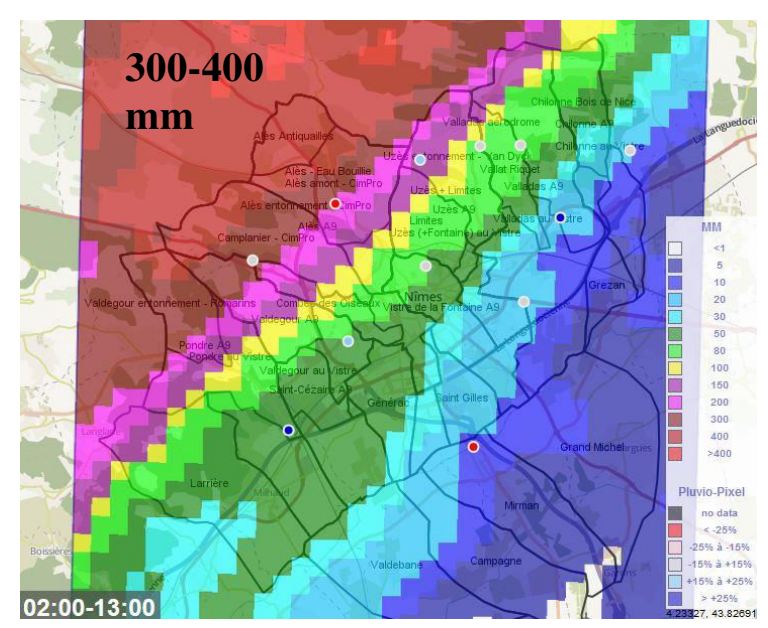

Figure 4. Accumulated rainfall estimated by radar between $2 \mathrm{am}$ and 1pm, October 10, 2014, over the Nîmes area (source: radar images of rainfall, $0.25 \mathrm{~km}^{2}$ pixel Rhea_Kisters/MétéoFrance/Ville de Nîmes (C). 
Cumulated rainfalls on upstream catchment areas were very high:

- 278 to $289 \mathrm{~mm}$ on catchment areas of approximately $1 \mathrm{~km}^{2}$;

- $285 \mathrm{~mm}$ on a $3.5 \mathrm{~km}^{2}$ catchment area;

- $266 \mathrm{~mm}$ on the $7.3 \mathrm{~km}^{2}$ Roquemaillère dam catchment area.

Amongst the nine raingauges managed by the city of Nîmes, the highest intensities and total rainfalls were recorded at Castanet (see Table 1):

\begin{tabular}{|c|c|c|c|}
\hline Duration & $\begin{array}{c}\text { Maximum } \\
\text { total } \\
\text { rainfall } \\
(\mathrm{mm})\end{array}$ & $\begin{array}{c}\text { Average } \\
\text { intensity } \\
(\mathrm{mm} / \mathrm{h})\end{array}$ & $\begin{array}{c}\text { SHYREG } \\
\text { return }^{\text {period }} \\
\text { a }\end{array}$ \\
\hline $5 \mathrm{~min}$ & 14.4 & 172.8 & $\begin{array}{c}10-20 \\
\text { years }\end{array}$ \\
\hline $15 \mathrm{~min}$ & 34.4 & 137.6 & $\begin{array}{c}20-50 \\
\text { years }\end{array}$ \\
\hline $30 \mathrm{~min}$ & 65.8 & 131.6 & $\begin{array}{c}>100 \\
\text { years }\end{array}$ \\
\hline $1 \mathrm{~h}$ & 101.6 & 101.6 & $\begin{array}{c}>100 \\
\text { years }\end{array}$ \\
\hline $12 \mathrm{~h}$ & 244.6 & 20.4 & $\begin{array}{c}>100 \\
\text { years }\end{array}$ \\
\hline
\end{tabular}

Table 1. Accumulated rainfalls recorded at the Castanet raingauge for various rainfall duration and estimated associated return periods.

Relatively significant flooding was reported on the upstream part of the Alès Cadereau, into which all the retention basins spilled. The City centre was spared from floods thanks to a water channel whose hydraulic capacity $(120 \mathrm{~m} 3 / \mathrm{s})$ was nearly entirely used.

The city of Nîmes was able to monitor the event in real-time thanks to its Flood warning system called ESPADA (French acronym for Evaluation et Suivi des Précipitations en Agglomération pour Devancer l'Alerte, Evaluation and Monitoring of Precipitations in Urban Communities as an Early Warning System). It forecasts risk levels and therefore enables to anticipate the actions listed in the city of Nîmes Local Emergency Action Plan (Plan Communal de Sauvegarde). Hydrological forecastings rests on IRSTEA's GR4H-type model (see Fig. 5) [5] which uses as input data raingauges data and water-level sensors data, rainfall radar observations and rainfall forecasting. This rainfall-runoff model is enhanced thanks to an additional reservoir which represents the role and behavior of karst $[6,7]$.

${ }^{a}$ IRSTEA and Météo-France regional database of rainfall.

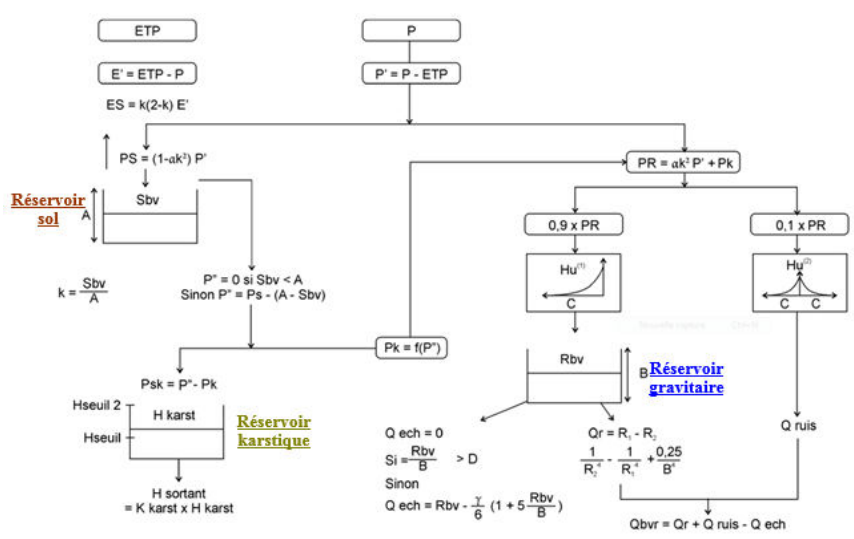

Figure 5. Schematic layout of the ESPADA hydrological model.

\subsection{General behavior of the hydraulic structures during the event and post-event correcting works}

During the event, only the flood mitigation structures located on the western part of the Cadereaux catchment areas were needed. Representing a storing capacity of $537,000 \mathrm{~m}^{3}$, they were able to temporarily stock 445,000 $\mathrm{m}^{3}$. The flood mitigation capacity of eight of these structures was exceeded, triggering safety spillways.

Post-flood visits were carried out by a consultancy on October 14, 2014. They did not reveal any structural incidents. Only two hydraulic structures showed limited mechanical damage in their supporting foundations:

- slight regressive erosion at the left bank support on the Pont de la République Basin;

- erosion of the limestone strata that make up the downstream face of Anduze Basin's safety spillway.

The withdrawal of $\log$ jams and rocks was carried out soon after the event, on the 10th, 11th, and 12th of October 2014. The mechanical damages were corrected in January and February 2015 for a total cost of approximately $€ 300,000$. They consisted in slopes and rip-rap rectification at the Pont de la République Basin and in the modification of the Anduze basin spillway with the building of a reinforced concrete crest beam and the spraying of reinforced shotcrete concrete on the surface of the crest weir.

\subsection{The Roquemaillère Dam}

\subsubsection{Dam presentation}

The Roquemaillère dam is located on the upstream part of the Alès Cadereau at the outlet of a $7.3 \mathrm{~km}^{2}$ catchment area (see Fig. 6). 


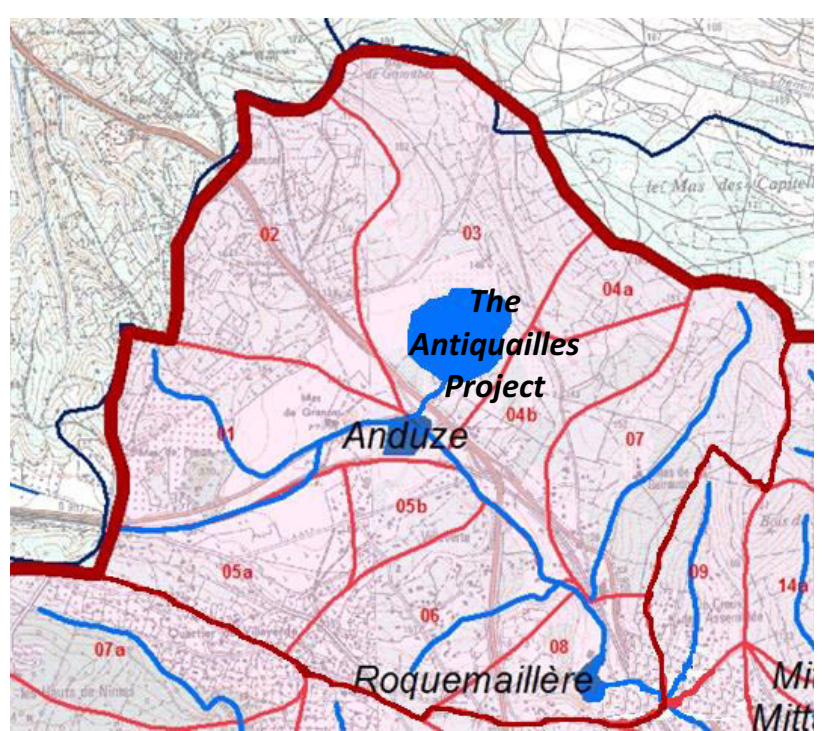

Figure 6. Catchment area of the Roquemaillère Basin.

It lies downstream from another flood attenuation basin (the Anduze Basin), and from a planned basinquarry project (Antiquailles), the purpose of which is to intercept runoffs at the first $\mathrm{km}^{2}$ of the catchment area. The Roquemaillère Basin was sized so as to mitigate a 40 -year flood on the catchment area of $3.3 \mathrm{~km}^{2}$ located between the Anduze Basin and itself.

Built in 1999-2000, the flood-mitigation dam is 6 meters high, and has a $70,000 \mathrm{~m}^{3}$ storage capacity. It is a backfill with an upstream facing and toe impervious key. The maximum discharge of its flood spillway is $307 \mathrm{~m}^{3} / \mathrm{s}$ (safety flood), while that of the bottom outlet is $14 \mathrm{~m}^{3} / \mathrm{s}$ at the normal reservoir level.

\subsubsection{Behavior during the 10/10/2014 flood}

During the event, the safety spillway of Roquemaillère dam was used as can be seen from Figure 7. The water level reached $90 \mathrm{~cm}$ above the safety spillway crest, corresponding to a $68 \mathrm{~m}^{3} / \mathrm{s}$ peak flow.

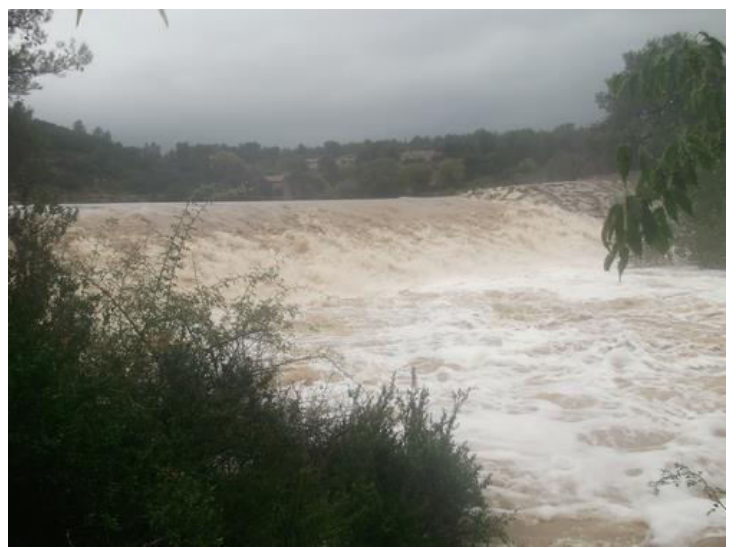

Figure 7. The Roquemaillère basin safety spillway, October 10, 2014, at 9:30, shortly before the flood peak (estimated $Q=$ $\left.68 \mathrm{~m}^{3} / \mathrm{s}\right)$.

\subsubsection{Hydrological analysis}

Hydrologic modeling of the ESPADA system gives a satisfactory representation of the flood hydrograph immediately downstream of the basins, notably in terms of peak flow (See Fig. 8).

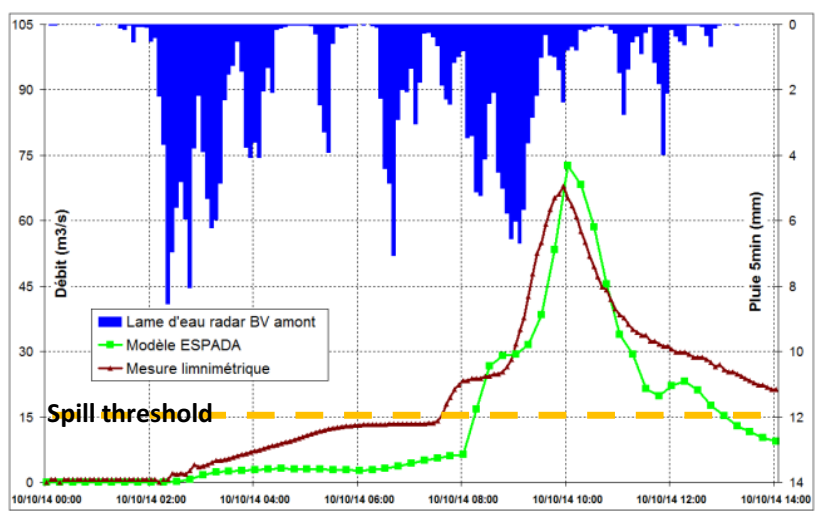

Figure 8. Calculated and observed output discharges downstream of the Roquemaillère Basin.

The peak flow computed by the ESPADA is $73 \mathrm{~m}^{3} / \mathrm{s}$, similar to the measured peak discharge of $68 \mathrm{~m}^{3} / \mathrm{s}$. What can be noticed is that the hydrologic model does not anticipate the discharge, the calculated discharge is indeed delayed from about 30 minutes. The spillway began to work at 7:40 am. At the 7:00 modeling run, the real-time model forecast that the spillway would start to work at 8:15, and confirmed this forecasting at the 7:30 run. The timing of the flood peak and of the recession curve are better forecast by the model.

In the current configuration for the Cadereau's upstream retention, the flood peak estimated for a centered, 2005-type event is $87 \mathrm{~m}^{3} / \mathrm{s}$ (which is a long-term objective-protection target). This centered 2005-type flood would trigger the basin's discharge as during the October 10, 2014 event.

To to reach the protection objective, the forthcoming Antiquailles Basin-quarry $(1.8 \mathrm{Mm} 3)$ is scheduled for completion. It will significantly reduce the runoffs and volumes due of the Cadereau, by controling the first 4 $\mathrm{km}^{2}$ of the catchment area. For an October 10, 2014-type event, the Antiquailles Basin would be able to stock over $550,000 \mathrm{~m} 3$, which would allow the Roquemaillère Basin to fully play its flood-attenuation role, by temporarily stocking the residual flood peak, whose volume is estimated at about 45,000 m3.

The hydrologic model also makes it possible to compare hydrographs calculated with or without the existing retention basins (see Fig. 9). The comparison of these hydrographs shows that the the Roquemaillère dam was able to play its flood-mitigation role at the beginning of the event. Thanks to its storage capacity, it would have enabled then a $50 \%$ reduction of the volume of water drained by the upstream watershed as shown on figure 9 by the dotted circle. It thus limited downstream runoffs in the morning of October, $10^{\text {th }}$ giving additional time to manage the episode. Due to its spillway entering into service at 7:40 am, the dam was however no longer able to play its flood mitigation role at the end of the event, in 
particular on the flood peak of $68 \mathrm{~m}^{3} / \mathrm{s}$ which happened at 10:00 am.

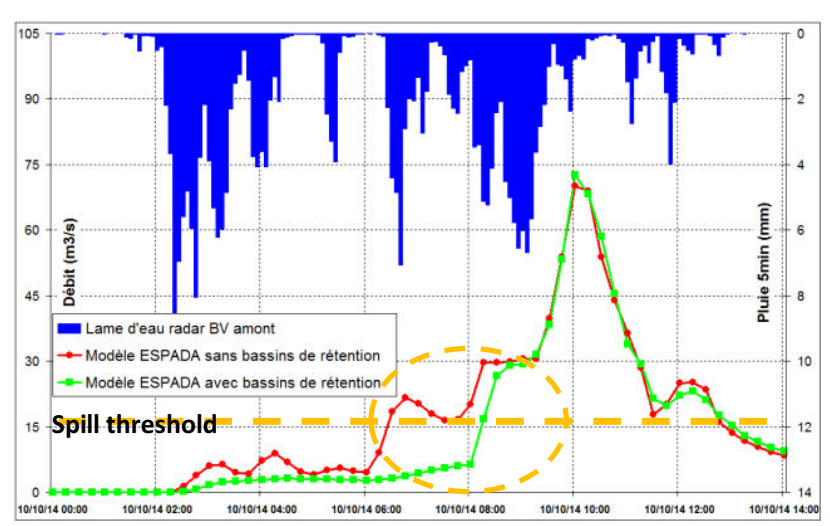

Figure 9. Calculated output discharges downstream of the Roquemaillère Basin. The hydrograph in red shows the discharges computed as if no hydraulic works were existing on the catchment, the hydrograph in green show the discharges computed with the current hydraulic retention basins (Roquemaillère and Anduze).

\section{Esquielle River Dam}

\subsection{Infrastructure Presentation}

\subsubsection{Project Background and Design}

The municipality of Saint Geniès de Malgoirès is adjacent to the city of Nîmes, which experienced exceptional 1988 floods. Due to its localized nature, the extreme event did not affect the village, but elected officials launched a study to evaluate the risk of floods on their territory. Completed in 1990, the study demonstrated how vulnerable the village centre was to floods of the Esquielle River. It was recommended that a flood-mitigation dam be built. Due to lack of funding, the structure was however not built.

On September $8^{\text {th }}$ and $9^{\text {th }}, 2002$, exceptional rainfall fell on the Département $d u$ Gard administrative area, particularly on the Esquielle River catchment area. The Esquielle River is a tributary of the Braune River which itself is a small tributary $(16 \mathrm{~km}$ long and a watershed of $109 \mathrm{~km}^{2}$ ) of the Gardon River. The $8.6 \mathrm{~km}^{2}$ catchment area of the Esquielle River was affected by $24 \mathrm{~h}$ rainfall exceeding $600 \mathrm{~mm} / 24 \mathrm{~h}$. Its peak discharge was estimated at $155 \mathrm{~m}^{3} / \mathrm{s}$. The river flooded 400 buildings during this event.

The event triggered a national call for the implementation of innovative actions plans for riskmanagement. The Plan d'Action de Prévention des Inondations $d u$ bassin versant des Gardons (Gardons River Catchment Area Flood-Prevention Action Plan PAPI) was chosen and renewed in 2013. Since then, the risk reduction strategy has been divided into several tasks: developing a culture of risk, improving risk management, adapting urbanism, reducing vulnerability, encouraging the river's natural flow, and implementing flood prevention works. Over a ten-year period, €43 million have been invested in these topics on the Gardons rivers.

The action plan was an opportunity to give new impulses to studies for the identification of realistic solutions to improve the flood situation. One of these studies focused on the village of Saint Geniès de Malgoirès. The development scheme that was carried out promoted the building of a flood-mitigation dam, as the 1990 study did. This time, the situation was different. Regional stakeholders had joined forces to form the Syndicat Mixte pour l'Aménagement et la Gestion Equilibrée des Gardons (Gardons SMAGE: Gardons Rivers Joint Union for Planning and Balanced Management), which became competent for building and operating dams. Furthermore, the Gardons rivers PAPI benefitted from significant funding.

Against this background, the Gardons SMAGE decided to build the Saint Geniès de Malgoirès floodmitigation dam (see Fig. 10) with fundings from european (20\%), national (40\%) and local levels (40\%). The dam was designed to avoid overflowing in the village for floods with a short return period (20 years), and to divide 100-year flood runoffs by two.

The hydraulic work program was supplemented by other actions such as laying flood height markers, teaching flood awareness in school, training elected officials, implementing the Local Emergency Action Plan (EAP) and the Flood Risk Prevention Plan (PPRi), reducing the vulnerability of public building and housings and maintaining watercourses.

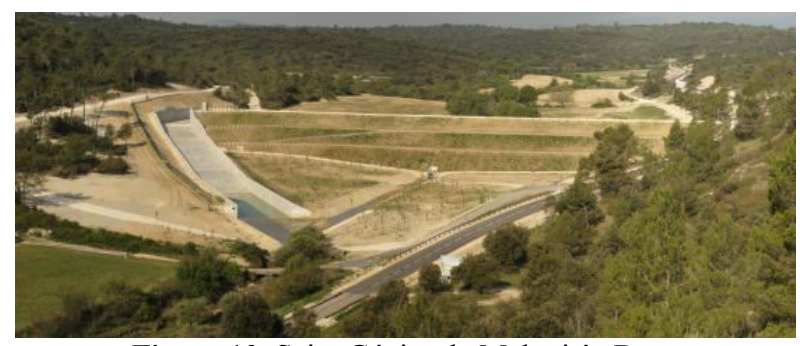

Figure 10. Saint Génies de Malgoirès Dam.

\subsubsection{Dam Construction}

The first difficulty was to find the best geographical location for the dam. The site identified by the 1990 study had lost its relevance because of the presence of a quarry. Two other upstream sites had been researched. But upon further investigation, it appeared that the geological context excluded the more downstream part of the valley (highly karstified area), and that building a single structure would be more economical. Additionally, it was necessary to acquire $22 \mathrm{ha}$ of land, and to move a power line and a departmental road from the bottom of a valley to the side of a hill.

The dam comprises a zoned embankment: a clay core rests on upstream and downstream shoulder. It is $14 \mathrm{~m}$ high and $205 \mathrm{~m}$ long, and has a drainage system (see Fig. 11). A bottom outlet enables to evacuate the Esquielle River's usual runoffs. A runoff-reducing plate limits the bottom outlet section to $50 \mathrm{~cm}$ by $40 \mathrm{~cm}$, the output discharge is then limited to 1 to $2 \mathrm{~m}^{3} / \mathrm{s}$, thus allowing a 
very quick filling of the reservoir. A $176 \mathrm{~m}$-long flood gate has been placed on the right bank, based on the rock. The spillway is $12 \mathrm{~m}$ wide and $4.2 \mathrm{~m}$ high.

The reservoir can hold $323,000 \mathrm{~m}^{3}$ up to the level of the flood gate's safety spillway, which is nearly the entire volume of a 20 -year return period flood (project flood). Floods of a smaller return period can thus be avoided downstream. In case of a 100-year flood, the flood gate divides the inflow discharge by two. The consequences of a 100-year flood are reduced to that of a flood with a 20 -year return period. Water levels in the village are reduced by $1 \mathrm{~m}$. An additional volume of $477,000 \mathrm{~m}^{3}$ is available to attenuate more significant floods.

For floods exceeding the 100-year flood, the purpose of the flood gate is to ensure the safety of the structure. It evacuates a 10,000-year flood with a one meter freeboard.

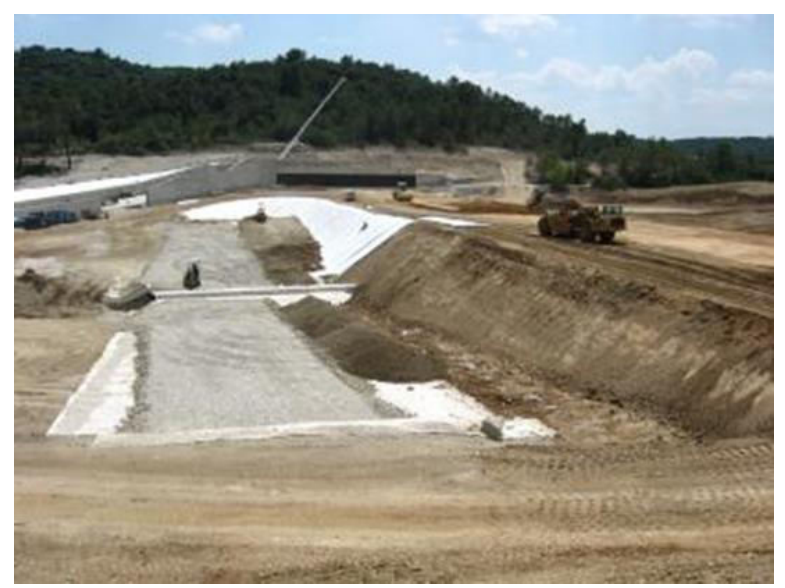

Figure 11. Dam construction site: view of the zoned shell, the bottom sluice, the drainage geotextile, the waterproof core, and the flood gate.

\subsubsection{Dam management and monitoring}

The Gardons SMAGE was the dam engineer, as well as its manager. As such, it carries on routine visits and structure maintenance. It also produces the regulatory documents: risk assessment, monitoring and management requirements in the event of a flood, in-depth technical visit report, monitoring report, flood state declarations. It carries out quarterly visits of the dam as well as visits in case of hydrometeorological events, when the reservoir is full and after it has been emptied.

Monitoring survey markers were implemented when the structure was built. Their movements were first tracked monthly, then on a yearly basis. The monitoring report contains an analysis and summary of these data.

To facilitate its day-to-day operation, the dam is equipped with a remote surveillance system that monitor the water surface level and the rainfall. This system delivers alerts when on-site measurements of rainfall and water levels reach pre-defined thresholds: $14 \mathrm{~mm}$ of rainfall in 15 minutes and/or a significant filling of the reservoir. The monitored data are delivered in real time to the Gardons SMAGE on-call staff and to the local Flood Forecast Service. The Gardons SMAGE also activates a hydro-meteorological monitoring as soon as the French
National Weather Service, Météo France, delivers the level 3 out of 4 of its vigilance system for the "storm, rain, and flood" hazard. The catchment area intercepted by the dam is hilly and covered in brushwood. It does not generate any significant sediment transport, nor floating debris. Reservoir maintenance occurs through horses grazing. The dam's downstream face is covered in vegetation. Maintenance is mechanical. The upstream face, covered in mineral lining (rip-rap), is maintained by hand to avoid the use of chemicals.

\subsection{Behavior of the dam during the Autumn 2014 events}

During the Autumn 2014 events, the Saint Geniès de Malgoirès dam experienced three floods, triggering flood gate operation for the first time since its building. These floods occurred on September $17^{\text {th }}$ and $29^{\text {th }}$, and October $10^{\text {th }}, 2014$. Reservoir water levels exceeded $9 \mathrm{~m}$, with floods rising at a speed of $8 \mathrm{~m}$ in 2 hours. Water height on the flood gate spillway reached $20 \mathrm{~cm}$. The flood gate was only in operation for several hours for each event. The reservoir drainage time was in the 3-day range. The real time hydro-meteorological monitoring stopped when the reservoir was fully drained.

Visits were organized during the event while the structure contained water and during its drainage (See Fig. 12). These guaranteed that the structure was operating properly. A very small amount of debris was found at the dam level. No emergency intervention was required. A clean-up operation was programed for the piezometric sensors and the plant debris on the dam upstream face and at the level of the flood gate. The only significant element was that covering sealants were ripped off the spaces between the concrete blocks of the flood gate. Being too rigid, they cracked and have been damaged prematurely. Sealants were replaced early 2015. As it was the flood gate's first filling, it was decided, during an in-depth technical visit, to empty and clean the energy dissipation hole of the flood gate. This further confirmed that this permanently immersed part of the structure was in a healthy state. Suspended matter was found at the bottom of the pit.

A report from the monitoring system was carried out late 2014, following the events. No significant movement was observed in the structure. Only a minimal settlement, occurring since the structure's completion, was identified. A flood report was drawn up for each of the three events that flooded the flood gate. It was handed to government services responsible for monitoring the safety of hydraulic works (DREAL).

From a hydrological perspective, the reconstructed inflows show that the flood volumes remained lower than that of the design hydrographs. Hence, peak flows came close to a 100-year flood, while volumes remained at the level of a 10-year flood. The dam operated in conformity with its sizing, and did not experience any significant disruption. The entire flood volume was stocked, and no flood were observed downstream from the dam. We can therefore conclude that the structure avoided the flooding of the village of Saint Geniès during these three events. 

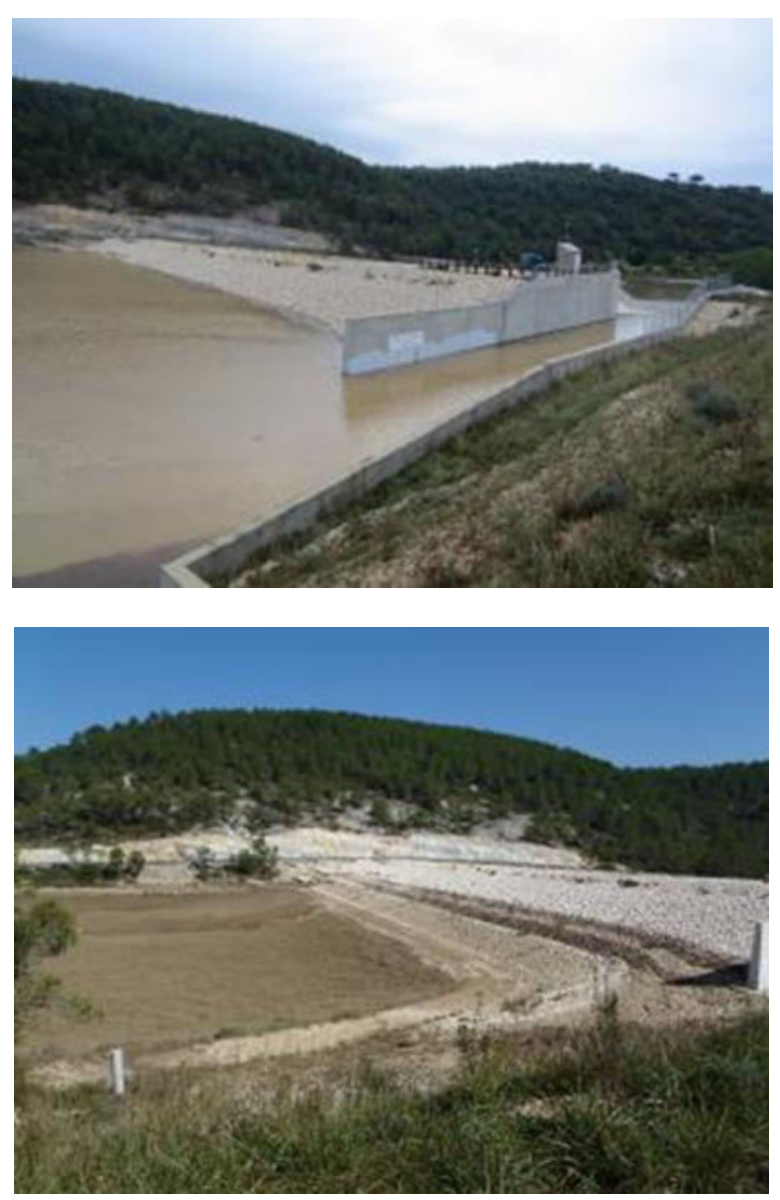

Figure 12. Dam during one of the flood events: during the event (top) / after it has drained (bottom).

\subsection{Hydrological Analysis of the Dam During the September 17, 2014 Event}

\subsubsection{Event Description}

The event that occurred from September 16th to 20th, 2014, was the first of a series of intense rain events that affected the French Mediterranean Departments the autumn of 2014. These manifested through a series of storm and rainfall activities, with a first wave of storms occurring over the Gard Department in the night between September 17 and 18th, 2014, and a second one in the night between September 19 and 20th, 2014. The first of these storms affected the Esquielle River's catchment area.

The event's hydro-meteorological sequence of events on the Esquielle Basin was reconstituted using different data:

- Météo France meteorological radar data, available at

15-minute time steps,

- 5-minute time step recording of the raingauge located in front of the dam,

- 5-minute time step recording of the water surface level.

Between September 17 and 20th, the catchment area upstream of the dam collected a total precipitation of 208 $\mathrm{mm}$ estimated by radar data. This measurement was validated by the raingauge on the structure, with a total rainfall of $218 \mathrm{~mm}$. This last recording distinguishes two phases in the September 17-18 rainfall event:

- a first stormy episode, which brought a total rainfall of $65 \mathrm{~mm}$ between 12.00 and 19:00,

- a second episode which hit the area from 22:00 on, with a total rainfall of $125 \mathrm{~mm}$ in 7 hours, $55 \mathrm{~mm}$ of which fell between 23:00 and midnight.

The water surface rose following these two phases, with:

- a slight filling occurring at 13:00 on September 17, going from a 111.9 NGF [nivellement général de la France, General Leveling of France] level (empty reservoir) to an 114.6 NGF level, followed by a swift drainage and returning to an empty reservoir at 21:00,

- then a swift filling from $22: 45$, with a rise of nearly $8 \mathrm{~m}$ in 2 hours, the 119.5 NGF level being reached at 0:50 on September 18. After this, the progression slowed down. The flood gate was activated at 5:20, for five hours. The maximal $120.70 \mathrm{NGF}$ level was reached at $6: 20$. Following this, the reservoir was drained periodically. It reached the $112 \mathrm{~m} \mathrm{NGF}$ level at 4:00 on September 21, for a total drainage duration of three days.

Based on the reservoir's height-volume curve and recorded data, a hydrograph of the Esquielle was determined at the reservoir input. The first afternoon event only generated a $8 \mathrm{~m} 3 / \mathrm{s}$ peak flow. The second one reached $83 \mathrm{~m} 3 / \mathrm{s}$. The flood was defined by the speed of its rising waters and its brevity - under an hour. As the flood volume had been entirely stocked by the dam, the flood runoff was completely lowered and reduced to the bottom sluice runoff, at about $2 \mathrm{~m} 3 / \mathrm{s}$.

\subsubsection{Hydrometeorological Analysis of the Event}

The AIGA method developed by IRSTEA made it possible to conduct a hydro-meteorological analysis of the September 17, 2014 event over the Esquielle catchment area. The AIGA threshold warning system compares real-time rainfall and runoff data with frequency estimates of rainfall and runoff [8]. The realtime rainfall data are the radar rainfall accumulation information for different durations ( 1 hour, 2 hours, ... 72 hours) provided every 15 minutes by the meteorological radar network at the spatial resolution of $1 \mathrm{~km} 2$. These data are compared to regionalized rainfall frequency estimates computed for the same durations and at the same $1 \mathrm{~km}^{2}$ spatial resolution and for different return periods on the whole French territory [9]. Rainfall warnings are then provided on maps displaying the estimated return periods of the different radar rainfall accumulations for the ongoing event. The real-time runoff data are provided by a distributed hydrological model fed by the 1-hour radar rainfall grids and run every $15 \mathrm{~min}$ at a $1-\mathrm{km} 2$ resolution $[1,2]$. It produces real-time peak discharge estimates along the river network which are compared to regionalized flood frequency estimates [10]. Runoff warnings are then provided on a river network map according to the estimated return period of the computed peak discharge. The main interest of the AIGA method, implemented in the RHYTMME warning 
system [11], is to be able to deliver to operational services rainfall warnings in any point of their area of interest and runoff warnings anywhere on the river network they monitor, even at ungauged locations.

The comparison of SHYREG rainfall quantiles with maximal hourly radar rainfall during the event, using a spatial resolution in $\mathrm{km}^{2}$, shows that the return period for these rainfall events is in the range of 5 to 37 years.

The figure 13 shows the hydrograph modeled using the AIGA method and the hydrograph that has been reconstituted at the reservoir input. It is worth underlying that the AIGA method implemented here is the $1 \mathrm{st}$ version of the method which was calibrated on the runoff values of 160 watersheds located in Southeastern France [1]. The method was not locally based on the Esquielle watershed discharge values. Runoff data that can be reconstituted from measurements of water surface levels are an interesting opportunity to test the method performance. This comparison shows that the flood's overall dynamic is adequately reproduced, with a 30minute anticipation of the flood peak, and a similar anticipation of 2-year and 10-year quantiles, these peak excesses defining the first two levels of alert proposed by the method.

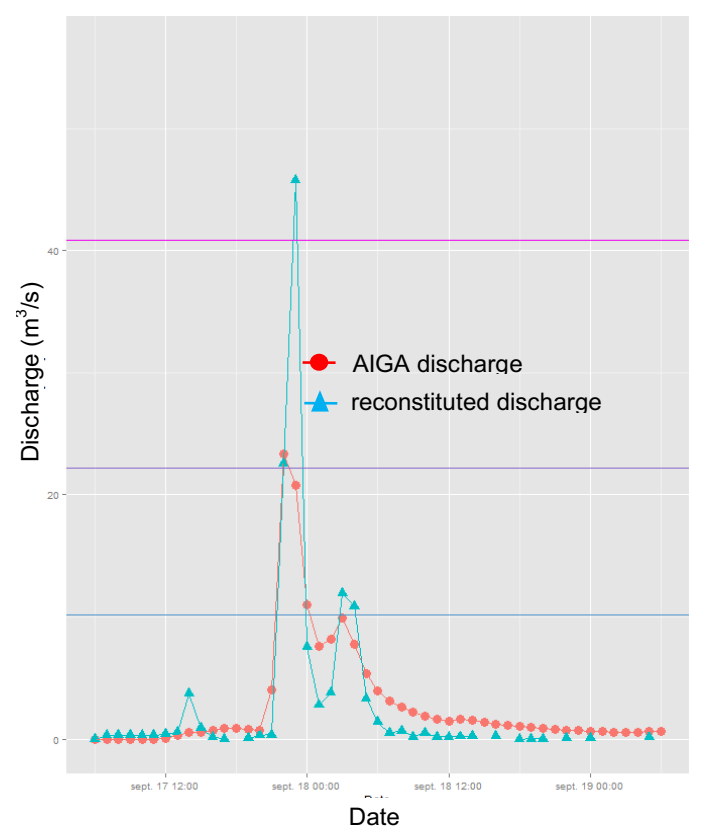

Figure 13. Input and modeled hydrographs on $9 / 17 / 2014$ at the Esquielle dam.

\section{Conclusion}

Building a flood-mitigation dam is often an interesting safeguarding strategy to protect existing stakes with regard to risks caused by flash floods. In France, this type of construction can receive public support, especially through PAPI programs, provided they are included in an overall reasonable catchment area strategy.

However, given obvious technical and economic constraints (topographic, land-use, geo-technical, environmental...), storage capacities in such structures are most of the time restricted to volumes ranging from tens to hundreds of thousands of $\mathrm{m} 3$ and, depending on sites, their protective role is generally only optimal for current ( 5 to 10 -year return periods) or rare floods ( 30 to 50 -year return periods). Facing exceptional or extreme events (with return periods above hundreds or thousands of years), French regulations require that such structures support resulting floods without serious structural damage, and using an adequately sized flood gate.

During the rain and storm events that occurred in the Nîmes region in the Autumn of 2014, many dams and flood-mitigation dams, which had been recently built, were needed - some by lesser events, or events that were close to their protection project flood (such as the Saint Geniès de Malgoirès dam), others by more intense events (Roquemaillère dam, in the absence of a retention dam with a high stock volume, planned for upstream, but not yet built).

In the first case, in Saint Geniès de Malgoirès, the effectiveness of the structure, including a flood gate that was operating for the first time, was demonstrated, and downstream stakes were totally preserved, owing to the fact that the peak runoff did not flow into the downstream canal.

In the second case, on the Roquemaillère dam in Nîmes, the attenuation effect was only felt at the onset of the flood, and it was especially important to ensure that the structure - particularly its flood evacuation - had not suffered any major damage thanks to its adequate sizing facing the hydrologic safety flood. Although it was ultimately exceeded during the event, the dam's mitigation capacity nonetheless allowed the town to initially limit downstream runoffs, notably in its dense urban area, and to buys some time while municipal safety measures were being triggered, in addition to its ESPADAC prediction system.

Regardless of the intensity of the floods they control or mitigate with each event, adequately managing the safety of such hydraulic structures must entail surveillance of dams, of their elements, and of their surroundings (visual assessments, clearing logjams, small maintenance, and, when necessary, repairs), especially after any significant flood. These actions are closely controlled by French regulation, which requires that directors of such structures define operating or dam monitoring instructions.

\section{References}

1. Javelle, P. et al. Evaluating flash-flood warnings at ungauged locations using post-event surveys: A case study with the AIGA warning system. Hydrological Sciences Journal, 2014, 59(7): p. 1390-1402.

2. Javelle, P., Fouchier, C., Arnaud, P., Lavabre, J. Flash flood warning at ungauged location using radar rainfall and antecedent soil moisture estimations. Journal of Hydrology, 2010, 394 (1-2): P 267-274.

3. Merckle S. and al. (2010). Small dams for flood control - specificities with regards to new [French] regulations. Colloque CFBR-AFEID "Sécurité des barrages et nouvelle réglementation française. 
Partage des méthodes et expériences, Lyon, France, 2010/11/09

4. Arnaud P., Aubert Y., Organde D., Cantet P., Fouchier C., Folton N. (2014). Hydro-meteorological risk estimation based on a flood generation model: SHYREG approach: The method, its performances and the associated database, La Houille Blanche, issue 2, April 2014, pp 20-26.

5. Raymond M. et al. (2007). "ESPADA": An innovative tool for real time urban flood management. Proceedings of NOVATECH 2007, pp. 793-800.

6. Fleury P. et al. (2010). Caractérisation des crues karstiques pour la mise en place d'un système d'alerte. Revue Géologues, $n^{\circ} 167$, décembre 2010,pp. 75-78.,

7. Fleury P. and Raymond M. (2010). Intégration de la composante «eaux souterraines karstiques » dans le système d'alerte de la Vile de Nîmes. BRGM Final Report, juin 2010, 175 p.

8. Lavabre, J. and Gregoris, Y. AIGA: a flood forecasting tool. Application to the French Mediterranean region. In Climate Variability and Change - Hydrological Impacts. IAHS Publication 308, p. 214-219.

9. Neppel, L. et al. Comparison of extreme rainfall frequency analysis methods in France. La Houille Blanche, 2014, (2): p. 14-19

10. Aubert, Y., P. Arnaud, P. Ribstein and J. A. Fine. The SHYREG flow method-application to 1605 basins in metropolitan France. Hydrological Sciences Journal, 2014, 59(5): 993-1005.

11. Fouchier C. et al. (2015). Implementation of a realtime warning and mapping system for natural hazards triggered by rainfall in moutainous and Mediterranean areas of Southeastern France. In Rainfall in Urban and Natural Systems, Proceedings of the 10th International Workshop on Precipitation in Urban Areas, 1-5 December 2015, Pontresina, Switzerland, 5 p. 